\title{
Relative Assessment of Some Toxins on Molecular Changes in the Protein Profile of Mugil Cephalus, Peaneaus Indicus and Protues Pelagicus Procured from some Estuaries of South East Coast of Indian Ocean
}

\section{Hassan Sulieman $\mathrm{MA}^{1 *}$ and El Amin $\mathrm{S}^{2}$}

${ }^{1}$ Department of Biology, Taibah University, Kingdom of Saudi Arabia

2Department of Zoology, King Saud University, Kingdom of Saudi Arabia

*Corresponding author: Hassan MA Sulieman, Department of Biology, College of Science, Yanbu Branch, Taibah University 039, Kingdom of Saudi Arabia, Tel: 00966538627401; Email: hassanadamus@yahoo.com

\section{Research Article \\ Volume 2 Issue 6}

Received Date: November 10, 2018

Published Date: December 06, 2018

DOI: $10.23880 /$ ijoac- 16000155

\section{Abstract}

Marine organisms namely Mugil cephalus, Portunus pelagicus, and Penaeus indicus were collected during post-monsoon, pre-monsoon and monsoon from Vellar and Uppanar estuaries, South East Coast of Indian Ocean. Muscle of considered species was examined for a presence of toxic metals ( $\mathrm{Al}, \mathrm{Cd}, \mathrm{Cu}, \mathrm{Pb}$ and $\mathrm{Zn}$ ), utilizing Inductively Coupled Optical Emission Spectrometry (ICP-OES). The outcome demonstrated the Aluminum concentration $(12.176 \mu \mathrm{g} / \mathrm{g}) \mathrm{had}$ a most extreme level in considered marine organisms at Uppanar estuary took after by zinc $(1.332 \mu \mathrm{g} / \mathrm{g})$, copper $(0.204 \mu \mathrm{g} / \mathrm{g})$, lead $(0.054 \mu \mathrm{g} / \mathrm{g})$ and cadmium $(0.004 \mu \mathrm{g} / \mathrm{g})$ when contrasted and Vellar estuary $\mathrm{Al}(2.084 \mu \mathrm{g} / \mathrm{g}), \mathrm{Zn}(0.307 \mu \mathrm{g} / \mathrm{g}), \mathrm{Cu}(0.145$ $\mu \mathrm{g} / \mathrm{g}), \mathrm{Pb}(0.054 \mu \mathrm{g} / \mathrm{g})$ and $\mathrm{Cd}(0.026 \mu \mathrm{g} / \mathrm{g})$. None of the toxic metals examined at Vellar and Uppanar estuaries was exceeding acceptable levels. The impact of these trace metals on protein were investigated quantitatively and subjectively. Likewise, utilizing sodium dodecyl sulfate-polyacrylamide gel electrophoresis (SDS-PAGE) and total protein estimation. The most level of total protein was found in Mugil cephalus muscle of (381.8mg/ml) in monsoon and Penaeus indicus $(377.0 \mathrm{mg} / \mathrm{ml})$ in pre-monsoon at Vellar estuary and the base level was found in Mugil cephalus (211.8mg/ml) at Uppanar estuary in the same season. Total protein level was watched lower in all test species of Uppanar estuary than the species of Vellar estuary. SDS-PAGE examination as protein profile demonstrating the little varieties in protein divisions in correlation among species gathered from two localities.

Keywords: Heavy Metals; Total Protein; Mullet; Shrimp; Crab 


\section{International Journal of Oceanography \& Aquaculture}

Abbreviations: ICP-OES: Inductively Coupled PlasmaOptical Emission Spectrometry; SDS-PAGE: Sodium Dodecyl Sulfate Polyacrylamide Gel Electrophoresis; ANOVA: Analysis of Variance; SIPCOT: State Industries Promotion Corporation of Tamil Nadu.

\section{Introduction}

Essential reports clarified that industrial and local effluent make biggest source of trace components which add to the continuously expanding a few contaminants in the marine environment in most portion of the World [1]. Heavy metals accumulated in the aquatic organisms by direct consumption of water and food through the digestive system or indirectly across the permeable membranes such as gills and skin. Concentration levels of heavy metals in fish organs indicate their levels in water and sediments. The level of accumulation of heavy metals in fish organs can exceed the environmental levels. The toxic effect usually occurs when the rate of uptake is exceeding the mechanism of metabolism, storage, and detoxification [2]. The rehashed employments of various wastes of industry, farming and local byproducts are principle sources of sullying into nature. These contaminants, when present by floods, streams or rains into water bodies can change the physical and substance of water qualities [3]. The contaminants are expanding the level of harmfulness, to fish as well as to all marine living things, which constitute natural ways of life of the marine creatures [4]. The levels of the heavy metals varied significantly among fish species and organs [5].

The impact of contaminants on some action of catalyst and protein profile of some marine life forms, for example, fish, had explored by various analysts Adedeji OB, et al. Ramalingam K, et al. Rashatwar SS, et al. \& Verma TS, et al. [6-9]. The ecological risk approach have been recorded and in perspective of biomarkers estimations of individuals and depending upon the way that movements happen at low levels of common relationship before the gathering is affected. Sub-nuclear changes are natural parameters, for instance, physiology, regular science, cell reliability; genomic structure and expression estimations. They are markers of either a common status, or changes in individuals of the gathering focused on. The use of bio-markers, for instance, protein level estimation and dodecyl-sulfate-polyarcylamide gel electrophoresis (SDS-PAGE) for regular security suggest a cautious learning of their natural limit. Taking after segments can realize a combination of abnormalities in the gills, gut, liver, kidney, muscle or brain of fishes. The power of these movements on marine living creatures depends on upon the particular estimations, for instance, physiological level, centralization of poisons and introduction time. Evaluation of subjective and quantitative changes in protein level as measured by sodium dodecyl sulfate polyarcylamide gel electrophoresis (SDS-PAGE) and protein estimation level can be connected with toxicological effects of heavy metals.

The purpose of this study was to investigate the effect of some toxins metals on subjective and quantitative changes in protein level of fish Mugil cephalus, Protrous pelagicus and Peneaus indicus procured from two particular estuaries on South East Coast of India, during post monsoon, pre monsoon and monsoon.

\section{Materials and Methods}

\section{Study Area}

The Uppanar estuary is located at Cuddalore (Lat $11^{\circ} 43^{\prime}$ Long $79^{\circ} 49^{\prime}$ ), which is about $25 \mathrm{~km}$ away from the Parangipettai coast It originates from the north eastern part of the Shervarayan hills and opens into the Bay of Bengal near Cuddalore city [10].

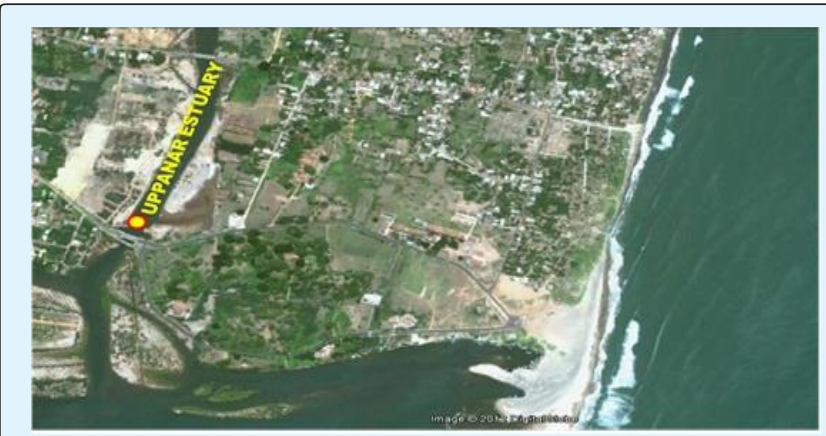

Figure 1: Shows study area Uppanar Estuary, South East Coast of India.

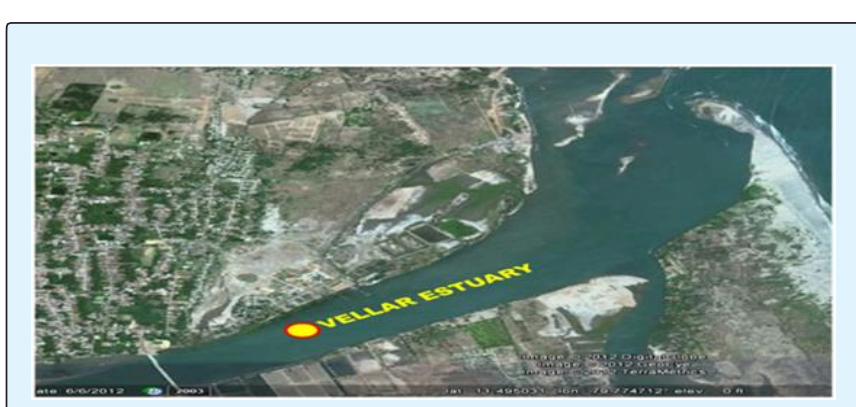

Figure 2: Showing study area Vellar Estuary, South East Coast of India. 


\section{International Journal of Oceanography \& Aquaculture}

Vellar estuary is situated on the southeast coast of India in Lat. $11^{\circ} 29^{\prime} \mathrm{N}$; Long $79^{\circ} 46^{\prime} \mathrm{E}$. It has a year round connection with the open sea. The Vellar estuary has been demarcated into marine, gradient, tidal and freshwater zones, Ramamurthy A, based on salinity characteristics [11].

\section{Sampling}

Three commercially important marine species representing different categories fish Mugil cephalus, Penaeus indicus and Portunus pelagicu were randomly selected and purchased from fishermen a live or newly caught from both estuaries Vellar and Uppanar, during post monsoon, pre-monsoon and monsoon seasons. Packed in cleaned sacs and transported to the laboratory in an ice-filled insulation box. The samples were transferred and hold on laboratory Deep-freezer at $-20^{\circ} \mathrm{C}$ to scale back biological deterioration before analysis. Five samples from each group of flesh muscles were manually cut into small pieces with stainless-steel scissors and sharpen knives. Then, the tissue was washed with Milli-Q water and dried at $80^{\circ} \mathrm{C}$ for $12 \mathrm{hrs}$ and ground into fine powder, using mortar and pestle. The dried tissue powder was measured precisely to the closest (1 gram) and exchanged to a glass container. $10 \mathrm{ml}$ of concentrated acid $\left(60 \% \mathrm{HNO}_{3}: 70 \% \mathrm{HCLO}_{4}\right)$ were added and left at room temperature for 12 hours. The processed specimens were heated gradually to $180^{\circ} \mathrm{C}$ till the sample volume was diminished to $2-3 \mathrm{ml}$. Every sample was filtered and made up to $25 \mathrm{ml}$ with Milli-Q water. The heavy metals were measured by Inductively Coupled Plasma Optical Emission Spectrometry (ICP-OES) using the following method:

a. Dried tissue powder weighed accurately to nearest (1 gram) and transferred to a glass beaker.

b. $10 \mathrm{ml}$ of concentrated acid (60\% HNO3: 70\% HCLO4) were added and covered with a slight excess of acid and left at room temperature for $12 \mathrm{hrs}$.

Metal Concentration ( $\mu \mathrm{g}^{-1}$ dry weight $)=$ AAS response (ppm) x volume of sample $(25 \mathrm{ml}) \times \mathrm{D}$

Weight of the tissue (gms, DW) $\times 1000$

c. The digested samples were heated slowly to $180 \mathrm{C}$ till the sample volume was reduced to $2-3 \mathrm{ml}$.

Where $\mathrm{D}=$ Dilution factor.

Statistical Analysis: The data were subjected to one way analysis of variance (ANOVA) using the package of
(IBM SPSS version 19.0) and the analysis were performed at 0.05 significance level.

\section{Total Protein Estimation and Electrophoresis (SDS-PAGE)}

Total protein concentration in the supernatant was resolved by strategy for Lowry $\mathrm{OH}$, et al. [12] and expressed in $\mathrm{mg} / \mathrm{ml}$ of wet mass. While the sodium dodecyl sulfate-polyacrylamide gel electrophoresis (SDSPAGE) was set up as indicated by the technique for Laemmli UK [13].

\section{Results}

\section{Toxic Metals}

The mean concentration of trace metals $\mathrm{Al}, \mathrm{Cd}, \mathrm{Cu}, \mathrm{Pb}$ and $\mathrm{Zn}$ ) in the muscle of mullet fish, crab and shrimp during various seasons were shown in Table 1 and illustrated by Figures 3-7. The finding of Aluminum concentration level was run from (0.49-1.78) in Mugil cephalus muscle; Portunus pelagicu $(0.553-0.660 \mu \mathrm{g} / \mathrm{g})$ and Penaeus indicus $(0.15-0.166 \mu \mathrm{g} / \mathrm{g}) ; \quad$ Cadmium measurement in Mugil cephalus changed from (0.005$0.013 \mu \mathrm{g} / \mathrm{g})$, in Portunus pelagicu from $(0.004-0.027 \mu \mathrm{g} / \mathrm{g})$ and from $(0.001-0.002 \mu \mathrm{g} / \mathrm{g}$ ) in Penaeus indicus; Copper in Mugil cephalus vacillated from ( $\quad 0.034-0.085 \mu \mathrm{g} / \mathrm{g}$ ), ortunus pelagicu from (0.061-0.204 $\mu \mathrm{g} / \mathrm{g})$ Penaeus indicus from $(0.082-0.200 \mu \mathrm{g} / \mathrm{g})$; Lead was extended $(0.009$ $0.026 \mu \mathrm{g} / \mathrm{g}$ ) in Mugil cephalus, Portunus pelagicu (0.013$0.237 \mu \mathrm{g} / \mathrm{g}$ ) in Portunus pelagicu and (0.007-0.268) in Penaeus indicus; zinc was recorded in Mugil cephalus $(0.074-0.176 \mu \mathrm{g} / \mathrm{g})$ Portunus pelagicu $(0.228-0.259 \mu \mathrm{g} / \mathrm{g})$ and Penaeus indicus $(0.088-0.233 \mu \mathrm{g} / \mathrm{g})$ at Vellar estuary, while the findings of heavy metals were differed in same species gathered from Uppanar and were observed to be run somewhere around $(1.618-12.176 \mu \mathrm{g} / \mathrm{g})$, Portunus pelagicu $(1.295-3.617 \mu \mathrm{g} / \mathrm{g})$, Penaeus indicus (0.004$0.092 \mu \mathrm{g} / \mathrm{g})$; Cadmium level varied from $0.005-$ $0.013 \mu \mathrm{g} / \mathrm{g}$ ) in Mugil cephalus muscle, from $(0.004-$ $0.027 \mu \mathrm{g} / \mathrm{g}$ ) in Portunus pelagicu, and from (0.001$0.002 \mu \mathrm{g} / \mathrm{g}$ ) in shrimp; Copper in Mugil cephalus was run from $(0.029-0.120 \mu \mathrm{g} / \mathrm{g})$, fluctuated in Portunus pelagicu muscle from $(0.204-0.243 \mu \mathrm{g} / \mathrm{g})$ and from $(0.010$ $0.032 \mu \mathrm{g} / \mathrm{g}$ ); the estimations of Lead was run between $(0.010-0.050 \mu \mathrm{g} / \mathrm{g})$ in Mugil cephalus, while in Portunus pelagicu was gone from $(0.011-0.023 \mu \mathrm{g} / \mathrm{g})$ Penaeus indicus from $(0.004-0.005 \mu \mathrm{g} / \mathrm{g})$; Zinc in Mugil cephalus from $(0.105-1.332 \mu \mathrm{g} / \mathrm{g})$, Portunus pelagicu from $(0.518-$ $0.744 \mu \mathrm{g} / \mathrm{g})$ and Penaeus indicus from $(0.158-0.166 \mu \mathrm{g} / \mathrm{g})$. 


\section{International Journal of Oceanography \& Aquaculture}

\begin{tabular}{|c|c|c|c|c|c|c|c|}
\hline Organism /Season & Estuary & T.Weight (g) & Al & Cd & Cu & Pb & Zn \\
\hline Post Monsoon & Vellar & & & & & & \\
\hline Mugil Cephalus & & 200.81 & 2.084 & 0.006 & 0.065 & 0.025 & 0.307 \\
\hline Portunus pelagicu & & 123.34 & 1.088 & 0.026 & 0.145 & 0.012 & 0.276 \\
\hline Penaeus indicus & & 23.88 & 1.184 & 0.001 & 0.028 & 0.005 & 0.063 \\
\hline Post Monsoon & Uppanar & & & & & & \\
\hline Mugil Cephalus & & 199.5 & 1.434 & 0.001 & 0.073 & 0.037 & 0.451 \\
\hline Portunus pelagicu & & 118.98 & 0.175 & 0.003 & 0.074 & 0.011 & 0.284 \\
\hline Penaeus indicus & & 25.88 & 0.383 & 0 & 0.011 & 0.006 & 0.029 \\
\hline Pre Monsoon & Vellar & & & & & & \\
\hline Mugil Cephalus & & 209.56 & 1.783 & 0.002 & 0.085 & 0.024 & 0.176 \\
\hline Portunus pelagicu & & 126.66 & 0.663 & 0.004 & 0.061 & 0.013 & 0.259 \\
\hline Penaeus indicus & & 22.53 & 0.148 & 0 & 0.2 & 0.007 & 0.088 \\
\hline Pre Monsoon & Uppanar & & & & & & \\
\hline Mugil Cephalus & & 212.2 & 12.176 & 0.005 & 0.12 & 0.05 & 1.332 \\
\hline Portunus pelagicu & & 119.9 & 3.617 & 0.004 & 0.204 & 0.023 & 0.744 \\
\hline Penaeus indicus & & 23 & 0.092 & 0.001 & 0.01 & 0.004 & 0.158 \\
\hline Monsoon & Vellar & & & & & & \\
\hline Mugil Cephalus & & 186.07 & 2.041 & 0.004 & 0.06 & 0.034 & 0.206 \\
\hline Portunus pelagicu & & 133.45 & 0.492 & 0.0002 & 0.089 & 0.054 & 0.146 \\
\hline Penaeus indicus & & 23.73 & 0.429 & 0.001 & 0.047 & 0.028 & 0.091 \\
\hline Monsoon & & & & & & \\
\hline Mugil Cephalus & & 196.95 & 5.918 & 0.005 & 0.101 & 0.11 & 0.5 \\
\hline Portunus pelagicu & & 116.52 & 0.483 & 0.002 & 0.025 & 0.005 & 0.15 \\
\hline Penaeus indicus & & 24.05 & 0.396 & 0.001 & 0.046 & 0.006 & 0.126 \\
\hline (I) & & & & & \\
\hline
\end{tabular}

Table 1: Mean concentration levels of toxic metals ( $\mu \mathrm{g} / \mathrm{g}$ dry weight) in studied marine organism (Magil cephalus, Protrous pelagicus, Peneaus indicus) during post, pre and monsoon.

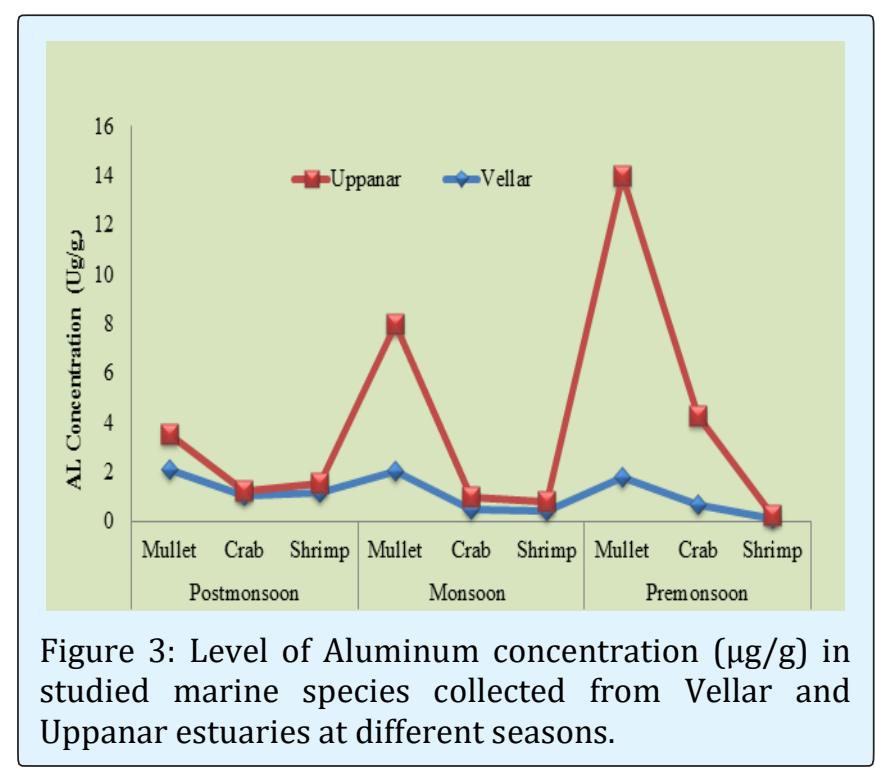

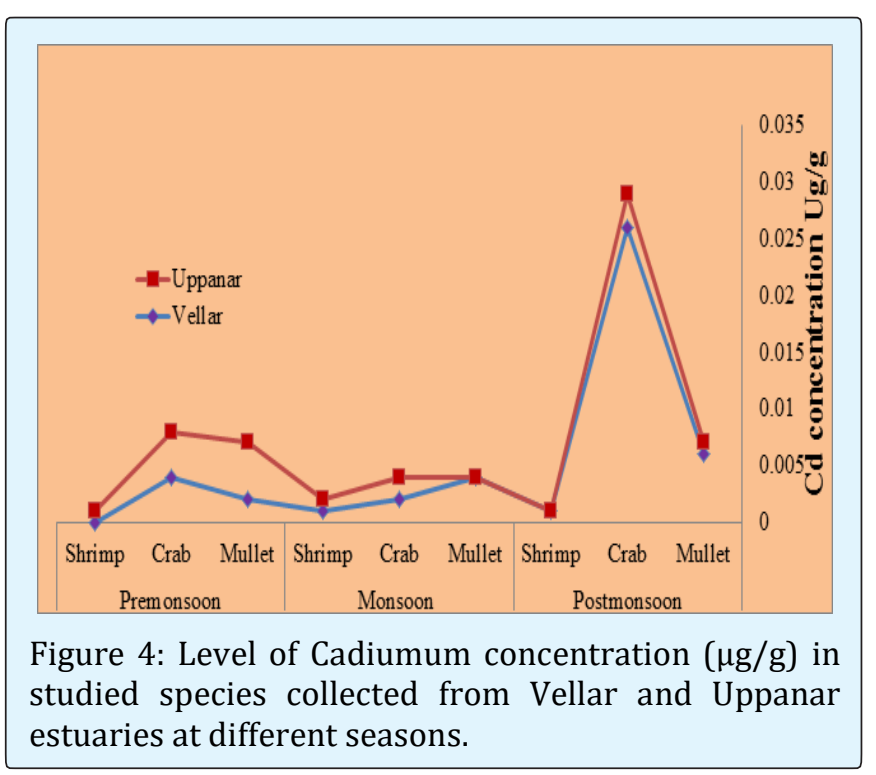




\section{International Journal of Oceanography \& Aquaculture}

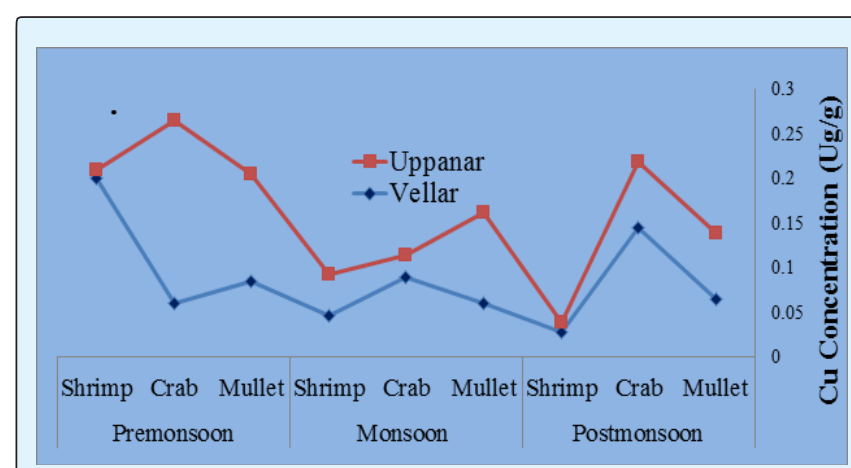

Figure 5: Level of Cupper concentration $(\mu \mathrm{g} / \mathrm{g})$ in studied marine species collected from Vellar and Uppanar estuaries at different seasons.

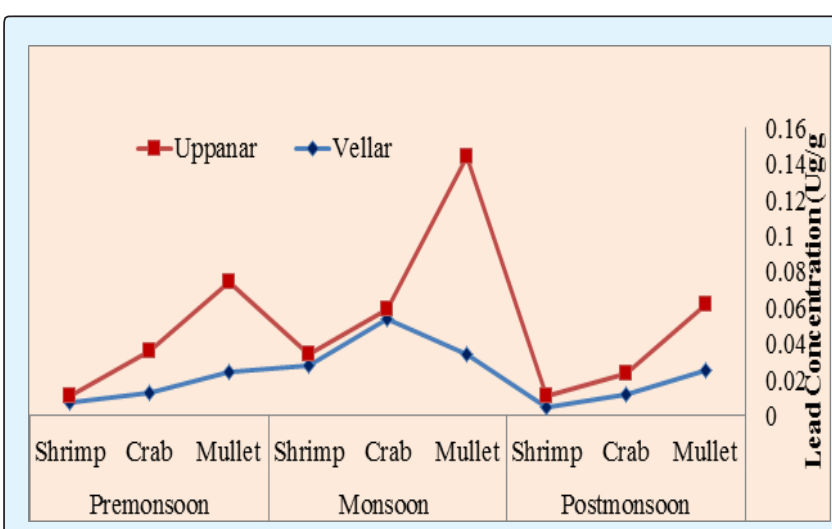

Figure 6: Level of Lead concentration $(\mu \mathrm{g} / \mathrm{g})$ in studied species collected from Vellar and Uppanar at different seasons.

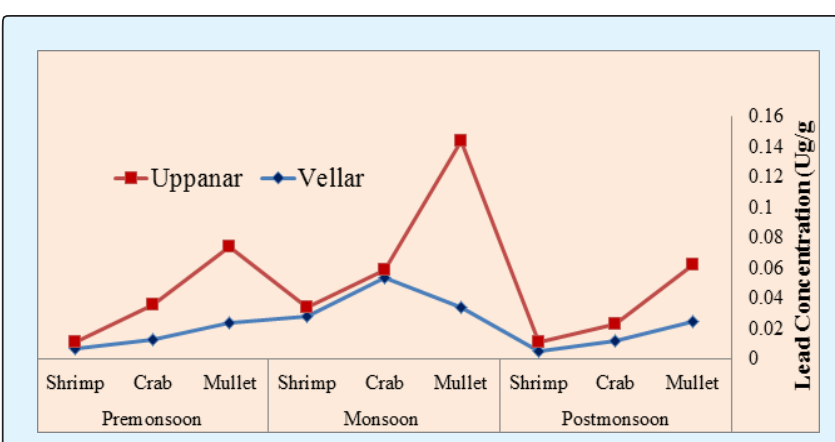

Figure 7: Level of Zinc concentration $(\mu \mathrm{g} / \mathrm{g})$ in studied marine species collected from Vellar and Uppnar estuaries.

\section{Protein Level}

Total protein concentration in the muscle of studied marine organisms beings at both destinations during seasons post monsoon, pre-monsoon and monsoon is displayed in Tables 2-4, Figure 8. Total protein qualities were varied from $(212.6-377.0 \mathrm{mg} / \mathrm{ml})$ in Penaeus indicus and extended somewhere around (211.8 and 381.0 $\mathrm{mg} / \mathrm{ml}$ ) in Mugil cephalus, while in Portunus pelagicus was ranged somewhere around 217.8 and $277.9 \mathrm{mg} / \mathrm{ml}$ at various seasons.

\begin{tabular}{|c|c|c|c|c|}
\hline Estuary & $\begin{array}{c}\text { Marine } \\
\text { Organism }\end{array}$ & $\begin{array}{c}\text { Post } \\
\text { Monsoon }\end{array}$ & $\begin{array}{c}\text { Pre } \\
\text { Monsoon }\end{array}$ & Monsoon \\
\hline Vellar & $\begin{array}{c}\text { Magli } \\
\text { cephalus }\end{array}$ & 247.2 & 265.8 & 218.6 \\
\hline & $\begin{array}{c}\text { Protrous } \\
\text { pelagicus }\end{array}$ & 217.8 & 335.8 & 265.6 \\
\hline $\begin{array}{c}\text { Peneaus } \\
\text { indicus }\end{array}$ & 218.8 & 377.0 & 246.2 \\
\hline Uppanar & $\begin{array}{c}\text { Magli } \\
\text { cephalus }\end{array}$ & 211.8 & 252.8 & 381.4 \\
\hline & $\begin{array}{c}\text { Protrous } \\
\text { pelagicus }\end{array}$ & 277.9 & 253.8 & 264.8 \\
\hline & $\begin{array}{c}\text { Peneaus } \\
\text { indicus }\end{array}$ & 212.6 & 216.6 & 245.8 \\
\hline
\end{tabular}

Table 2: Total protein levels $(\mathrm{mg} / \mathrm{ml})$ in selected marine organisms (Magil cephalus, Protrous pelagicus, Peneaus indicus) collected from Vellar and Uppanar during post, pre and monsoon.

\begin{tabular}{|c|c|c|c|c|c|c|}
\hline Parameter & \multicolumn{7}{|c|}{ Correlation Coefficients } \\
\hline Protein & & & & & & \\
\hline $\mathrm{Al}$ & $0.99^{* *}$ & & & & & \\
\hline $\mathrm{Cd}$ & -0.35 & -0.41 & & & & \\
\hline $\mathrm{Cu}$ & -0.23 & -0.29 & $0.99^{* *}$ & & & \\
\hline $\mathrm{Pb}$ & $0.92^{* *}$ & $0.90^{* *}$ & 0.02 & 0.14 & & \\
\hline $\mathrm{Zn}$ & 0.57 & 0.52 & 0.56 & 0.66 & 0.84 & 1 \\
\hline & Protein & $\mathrm{Al}$ & $\mathrm{Cd}$ & $\mathrm{Cu}$ & $\mathrm{Pb}$ & $\mathrm{Zn}$ \\
\hline
\end{tabular}

** Correlation is significant at the level 0.01

Table 3: Correlation coefficients among heavy metals and protein level of Magli cephalus, Protrous pelagicus and Peneaus indicus collected from Vellar estuary during different seasons.

\begin{tabular}{|c|c|c|c|c|c|}
\hline Locality & \multicolumn{3}{|c|}{ Mugil Cephalus } & $\begin{array}{c}\text { Portunus } \\
\text { pelagicu }\end{array}$ & $\begin{array}{c}\text { Penaeus } \\
\text { indicus }\end{array}$ \\
\hline & Muscle & Gill & Liver & Muscle & Muscle \\
\hline Uppanar & 9 & 10 & 10 & 4 & 7 \\
\hline Vellar & 10 & 11 & 9 & 9 & 7 \\
\hline
\end{tabular}

Table 4: Number of protein bands in different marine organisms collected from Vellar and Uppanar estuaries. 


\section{International Journal of Oceanography \& Aquaculture}

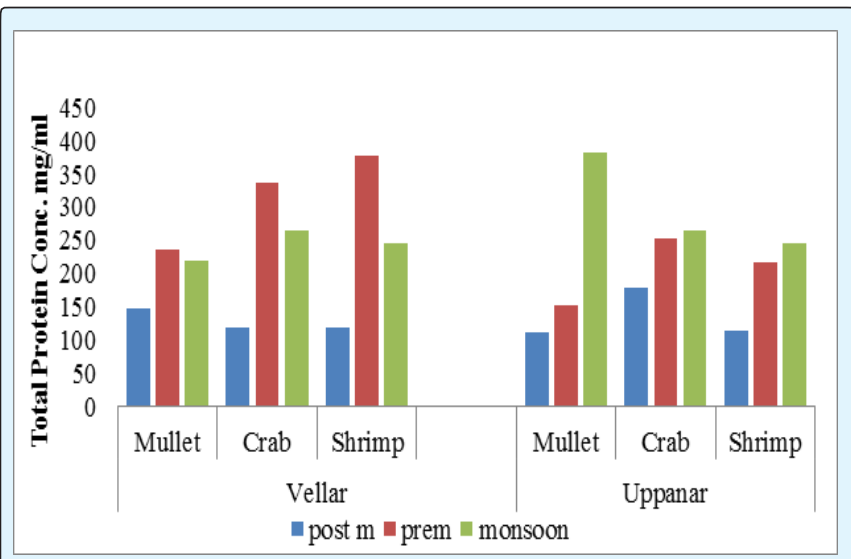

Figure 8: Total Protein Levels $(\mathrm{mg} / \mathrm{ml})$ in Shrimp, Crab and Mullet collected Vellar and Uppanar Estuaries during Premonsoon, Postmonsoon and monsoon.

\section{Discussion}

The result of the study revealed that $\mathrm{Al}, \mathrm{Cd}, \mathrm{Cu}, \mathrm{Pb}$ and $\mathrm{Zn}$ were accumulated significantly $(\mathrm{P}>0.05)$ in various concentrations in the target species muscles at Vellar and Uppanar estuaries. The concentration of Aluminum metal was observed maximum in Mugil cephalus $(12.176 \mu \mathrm{g} / \mathrm{g})$ during monsoon season at Uppanar estuary when compared with Vellar estuary. The maximum accumulation of $\mathrm{Al}$ in the muscle of Mugil cephalus fish might be because, the frequent use of Aluminum metal in all fishing gears and crafts during the fishing and handling of fish. In addition to these factors, the fish were collected from the Cuddalore fishing harbor which was situated near the mouth of the Uppanar estuary, and locating near to industrial area, park of State Industries Promotion Council of Tamil Nadu (SIPCOT), with other 44 factories. These industries act the main production lines of chemicals, petrochemicals, pharmaceutics, pesticides, fertilizers and metal processing industries in the south east of India, besides municipal and domestic sewage industrial effluents were regularly discharged into Uppanar estuary [10]. The minimum level of Cadmium $(0.001 \mu \mathrm{g} / \mathrm{g} \mu \mathrm{g})$ was seen in all tissue of studied marine organisms. Mostly the other trace metals $\mathrm{Cu}(0.061$ $0.200 \mu \mathrm{g} / \mathrm{g}), \mathrm{Pb}(0.013-0.026 \mu \mathrm{g} / \mathrm{g})$ and $\mathrm{Zn}(0.158-1.332$ $\mu \mathrm{g} / \mathrm{g}$ ) were recorded least amounts in both life form of estuaries contrasting and the passable level $(0.5-0.1 \mu \mathrm{g} / \mathrm{g})$ as showed by the Commission of The European Communities, Food U \& Standard C [14-16]. None of the trace metals examined was over the most extreme admissible level endorsed for human by world health associations [14-16].

The present results show that protein concentration level was significantly $(\mathrm{P}<0.01)$ highest and correlated positively with decreasing of metals values in all studied species. The total protein concentration of studied animal was significantly higher at Vellar than at Uppanar estuary in pre monsoon $(\mathrm{p}<0.01)$. These results suggested that, different metabolic activity of the investigated species depending on the season, level of pollutants and feeding localities as well as Vellar and Uppanar estuaries, and probably reflect the availability of food and feeding behavior of target species as indicated by Pazhanisamy $\mathrm{K}$ \& Inyang I, et al. $[17,18]$ Change in protein level of the different organisms of both estuaries was varied, the level of protein is observed in Penaeus indicus at Vellar was $(377.0 \mathrm{mg} / \mathrm{ml})$ at pre monsoon followed by Portunus pelagicu $(277.9 \mathrm{mg} / \mathrm{ml})$ and Mugil cephalus (265.8 $\mathrm{mg} / \mathrm{ml}$ ). The reduction of protein levels was appeared in Uppanar estuary when compared with Vellar estuary. These findings of protein level might be affected by high level of heavy metals in Uppanar estuary which was surrounded by SIPCOT industrial complex and they discharge waste into the estuary from time to time as reported by Karthikeyan R, et al. [10], however, Vellar estuary is assumed to be free from pollution. The Meanwhile the proteins are very sensitive to trace metals furthermore go about as one of the most punctual markers of trace metals harming as reported by Jacobs JM, et al. \& Neff JM $[19,20]$. They have reported that the exhaustion in protein qualities could be because of the enhancement of vitality to meet the approaching vitality requests when a creature under poisonous anxiety. As indicated by Reddy PM, et al. [21] examined, the protein consumption may mirror an earlier expanded expense of homeostasis, tissue-repair and detoxification under stress. Some of the poisons have demonstrated to change the protein digestion system in fish as reported by Palanichamy S, et al. \& Chitra K, et al. [22,23]. Likewise some of pollutants have considered changing the protein metabolism in fish as reported by Palanichamy S, et al. \& Chitra K, et al. [22,23]. The results of SDS-PAGE analysis of protein profile showing the little variations in protein fractions. Mugil cephalus gill from Vellar estuary showed the presence of 11 bands, while Mugil cephalus gill of Uppanar showed 10 bands. Subsequently, there is little an increase in protein bands in the species of Vellar estuary. Similarly the another organs show little variation in presence and absent protein bands ranged between 4 and 11, while the Mugil cephalus muscle collected from 


\section{International Journal of Oceanography \& Aquaculture}

Uppanar had showed the minimum reduction in protein bands and recorded 4bands only. Portunus pelagicu and Penaeus indicus showed the bands availability in two estuaries ranged from 4 to 9 , which are in consistent with the results of previous studies made elsewhere by Krishnamoorthy P, et al. [24] have studied the enzyme protein in kidney tissue of some fish by electrophoretically. They have reported the reduction in bands indicates the decreased level of enzyme protein due to pollution. Protein profile variation has been studied electrophoretically by Sharaf-Eldeen K, et al. [25] and they have observed the protein profile variations after animal subjected to the pollutants. The missing of existing polypeptide bands, the presence of new bands and changes in the intensity of protein portions demonstrate these impacts of toxicant on the physiology of the creature and on the vitality requests for the detoxification and disposal of toxicants, Anees M [26] found that the introduction of Oreochromis niloticus to the pollutants could be induced disappearance of certain serum protein parts Standard C [16] and Alabaster J, et al. [27] reported that the aggregate serum protein of Channa punctatus fish diminished essentially on presenting to some metallic compounds.

\section{Conclusion}

We concluded that, the different concentration of $\mathrm{Al}$, $\mathrm{Cd}, \mathrm{Cu}, \mathrm{Pb}$ and $\mathrm{Zn}$ in the muscle tissues of studied marine organisms collected from both estuaries during premonsoon, monsoon and post monsoon was found to be below the permissible level set by world health advisories. Metal measurements were higher in studied marine organisms of Uppanar in premonsoon than Vellar estuary in same time.

Total protein level was found to be lower in all species collected from Uppanar estuary than Vellar estuary, which indicated the presence of pollutants in Uppanar estuary. SDS-PAGE analysis as protein profile showing the little variations in protein fractions in comparison between the species collected from both estuaries (Figures $9 \& 10$ ).

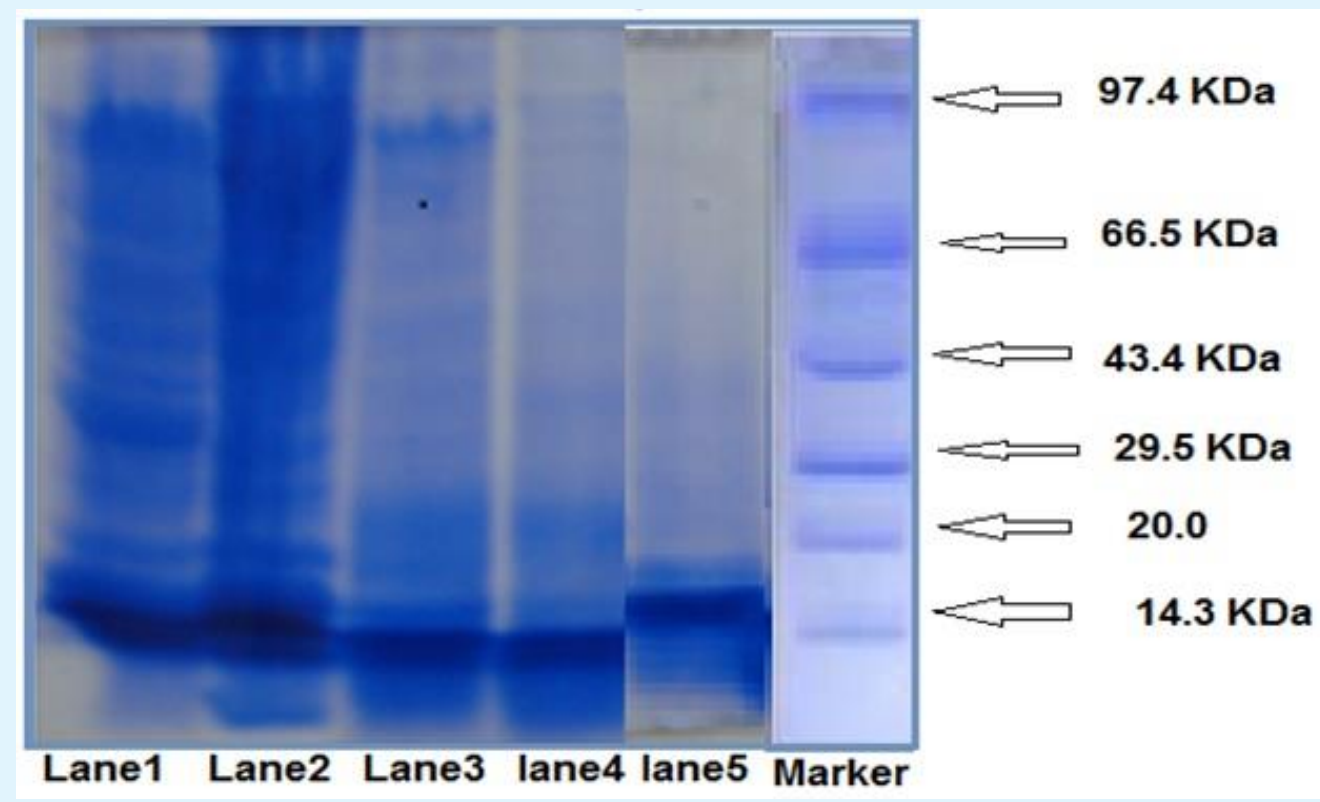

Figure 9: Sodium Dodecyl Sulphate Polyacrylamide Gel Electrophoresis (SDS-PAGE) analysis. Protein profile showing variations in protein fractions in comparison among the target marine species (Magil cephalus, Protrous pelagicus, Peneaus indicus) collected from Vellar estuary, South East Coast of India. Lane 1 Peneaus indicus muscle, Lane 2 Magil cephalus gill, Lane 3 Magil cephalus liver, Lane 4 Magil cephalus muscle, Lane 5 Protrous pelagicus muscle (protein standard marker, KDa= Kilo Dalton). 


\section{International Journal of Oceanography \& Aquaculture}

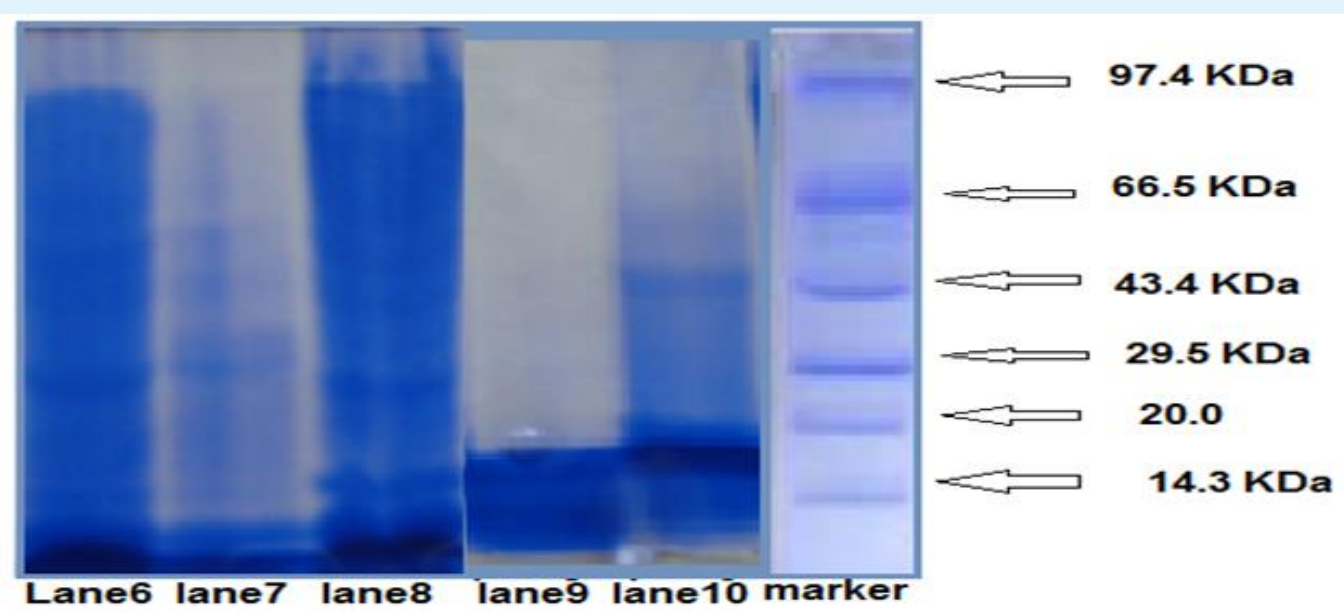

Figure 10: Sodium Dodecyl Sulphate Polyacrylamide Gel Electrophoresis (SDS-PAGE) analysis. Protein profile showing variations in protein fractions in comparison among the target marine species (Magil cephalus, Protrous pelagicus, Peneaus indicus) collected from Uppanar estuary, South East Coast of India. *Lane 6 Peneaus indicus muscle, Lane 7 Protrous pelagicus muscle. Lane 8 Magil cephalus muscle, Lane 9 Magil cephalus liver and lane 10 Magil cephalus gill. (Protein standard marker, KDa $=$ Kilo Dalton).

\section{References}

1. Olowu RA, Ayejuyo 00, Adewuyi GO, Adejoro IA, Denloye AAB, et al. (2010) Determination of heavy metals in fish tissues, water and sediment from Epe and Badagry Lagoons, Lagos, Nigeria. Journal of Chemistry 7(1): 215-221.

2. Rajeshkumar S, Li X (2018) Bioaccumulation of heavy metals in fish species from the Meiliang Bay, Taihu Lake, China. Toxicology Reports 5: 288-295.

3. Bhalchandra BW, Lonite VS (2001) Acute Toxicity of Pesticides Carbaryl and Endosulfan to Fresh Water Bivalve Parreysia Cylindrica. Pollution Research 20(1): 25-29.

4. Bandyopadhyay M, Aditya A (2002) Xenobiotic impact on sensitivity in Anabas testudineus (Bloch). Journal of Ecobiology 14(2): 117-124.

5. Bawuro AA, Voegborlo RB, Adimado AA (2018) Bioaccumulation of Heavy Metals in Some Tissues of Fish in Lake Geriyo, Adamawa State, Nigeria. Journal of Environmental and Public Health 2018: 7.

6. Adedeji OB, Adedeji AO, Adeyemo OK, Agbede SA (2008) Acute toxicity of diazinon to the African catfish (Clarias gariepinus). African Journal of Biotechnology 7(5).

7. Ramalingam K, Ramalingam K (1982) Effects of sublethal levels of DDT, malathion and mercury on tissue proteins of Sarotherodon mossambicus (Peters). Proceedings: Animal Sciences 91(6): 501505.

8. Rashatwar SS, Ilyas R (1983) Effect of chronic herbicide intoxication on in vivo activities of certain enzymes in the liver of freshwater fish Nemachelius denisonii (Day). Toxicology letters 16(3-4): 249-252.

9. Verma TS, Neue HU (1984) Effect of soil salinity level and zinc application on growth, yield, and nutrient composition of rice. Plant and Soil 82(1): 3-14.

10. Karthikeyan R, Vijayalakshmi S, Balasubramanian T (2007) Monthly variations of heavy metals and metal resistant bacteria from the Uppanar estuary (Southeast coast of India). Research J Microbiol 2(1): 50-57.

11. Ramamurthy A (1954) Preliminary study of the hydrology and fauna of Vellar estuary (South Arcot District). Proc Indo-Pacific Fish Coun Sym 9. 


\section{International Journal of Oceanography \& Aquaculture}

12. Lowry OH, Rosebrough NJ, Farr AL, Randall RJ (1951) Protein measurement with the Folin phenol reagent. J Biol Chem 193(1): 265-275.

13. Laemmli UK (1970) Cleavage of structural proteins during the assembly of the head of bacteriophage T4. Nature 227(5259): 680-685.

14. The Commission of The European Communities (2006) Commission Regulation (EC) No 1881/2006 of 19 December 2006 setting maximum levels for certain contaminants in foodstuff. Official Journal of the European Union: L364/5-L364/24.

15. (2001) Food U, Fish and Fisheries Products: Hazards and Controls Guidance. US Food and Drug Administration.

16. Standard C, General Standard for Contaminants and Toxins in Food and Feed (CODEX STAN 193-1995). Codex Alimentarius Commission of the Joint FAO. WHO Food Standards Programme.

17. Pazhanisamy K, Indra N (2007) Toxicity of arsenic on glycogen content in freshwater fish, Labeo rohita (Ham.). Nature Environment and Pollution Technology 6(2): 293-297.

18. Inyang IR, Daka ER, Ogamba EN (2010) Effects of sublethal concentrations of diazinon on total protein and transaminase activities in Clarias gariepinus. Current Research Journal of biological sciences 2(6): 390-395.

19. Jacobs JM, Carmichael N, Cavanagh JB (1977) Ultrastructural changes in the nervous system of rabbits poisoned with methyl mercury. Toxicology and applied pharmacology 39(2): 249-261.
20. Neff JM (1985) Use of biochemical measurements to detect pollutant-mediated damage to fish in Aquatic toxicology and hazard assessment: Seventh symposium. ASTM International.

21. Reddy PM, Bashamohideen MD (1988) Toxic impact of fenvalerate on the protein metabolism in the branchial tissue of a fish, Cyprinus carpio. Current Science 57(4): 211-212.

22. Palanichamy S, Arunachalam S, Baskaran P (1989) Effect of pesticides on protein metabolism in the freshwater catfish Mystus vittatus. Journal of Ecobiology 1(2): 90-97.

23. Chitra K, Kumar SR (1997) Effect of water pollution on peroxidase activity in fish, Channa gachua. Journal of Environmental Biology 18(2): 191-194.

24. Krishnamoorthy P, Subramanian P (1995) Biochemical variation during accumulation and depuration of copper in Macrobrachium lamarrei (HM Edwards). Bull Pure Anim Sci A 14: 27-33.

25. Sharaf Eldeen K, Abdel Hamid NA (2002) Sublethal Effects of copper sulfate, malathion and paraquat on protein pattern of Oreochromis niloticus. Egypt J Aquat Biol \& Fish 6(2): 167-182.

26. Anees M (1974) Changes in starch gel electrophoresis pattern of serum protein of fresh water teleost, Channa punctatus (Block), exposed to sublethal and chronic levels of three organophosphorous insecticides. Ceylon J Sci 11: 53-58.

27. Alabaster J, Lloyd R (1980) Water quality criteria for freshwater fish. Buttersworth, Inc. Boston, Massachusetts $2^{\text {nd }}$ (Edn.), pp: 382. 